\title{
Naming a phantom - the quest to find the identity of Ulluchu, an unidentified ceremonial plant of the Moche culture in Northern Peru
}

\author{
Rainer W Bussmann*1 and Douglas Sharon²
}

Address: ${ }^{1}$ William L Brown Center, Missouri Botanical Garden, PO Box 299, St. Louis, MO 63166-0299, USA and 22328 Dolphin Dr, Richmond, CA 94804, USA

Email: Rainer W Bussmann* - rainer.bussmann@mobot.org; Douglas Sharon - dk_sharon@sbc.global.net

* Corresponding author

Published: 31 March 2009

Journal of Ethnobiology and Ethnomedicine 2009, 5:8 doi:10.1186/1746-4269-5-8

This article is available from: http://www.ethnobiomed.com/content/5/I/8

(C) 2009 Bussmann and Sharon; licensee BioMed Central Ltd.

This is an Open Access article distributed under the terms of the Creative Commons Attribution License (http://creativecommons.org/licenses/by/2.0), which permits unrestricted use, distribution, and reproduction in any medium, provided the original work is properly cited.
Received: 26 January 2009

Accepted: 31 March 2009

\begin{abstract}
The botanical identification of Ulluchu, an iconic fruit frequently depicted in the art of the preColumbian Moche culture that flourished from A.D. 100-800 on the Peruvian north coast, has eluded scientists since its documentation in ceramics in the 1930s. Moche fine-line drawings of Ulluchu normally depict seed-pods or seeds floating in the air in sacrificial scenes, associated with runners and messengers or intoxicated priests. It is a grooved, comma-shaped fruit with an enlarged calyx found mainly in fine-line scenes painted on Moche ceramics. The term first appeared without linguistic explanation in the work of pioneer Moche scholar Rafael Larco Hoyle, and the identification of the plant was seen as the largest remaining challenge in current archaebotany at the Peruvian North coast. The name Ulluchu seems to have been coined by Larco. According to his description, the name originated in the Virú River valley, and is supposedly of Mochica origin. However, there is no linguistic evidence that such a term indeed existed in the Mochica or Yunga language.

We conclude that Ulluchu can be identified as a group of species of the genus Guarea (Meliaceae) based on morphological characteristics. In addition, the chemical composition of the plant's compounds supports the thesis that it was used in a sacrificial context to improve the extraction of blood from sacrificial victims. We also suggest that a ground preparation of Guarea seeds, when inhaled, may have been used as a hallucinogen. However, more detailed phytochemical research is needed to corroborate the latter hypothesis.
\end{abstract}

\section{Background}

Ulluchu is the common name assigned to a plant frequently depicted in the art of the Moche culture, which thrived on the north coast of Peru from A.D. 100 to 800 . It is a grooved, comma-shaped fruit with an enlarged calyx found mainly in fine-line scenes painted on Moche ceramics. The term first appeared without linguistic expla- nation in the work of pioneer Moche scholar Rafael Larco Hoyle ([1] Fig. Fifty-eight: [2] Fig. Ninety-eight, Figs. One hundred and sixty-six and sixty-seven). In his 1939 publication, he reported that the peoples of the sierras and the coastal region (Viru and Moche valleys) believed that the fruit had to be picked silently to prevent it from turning bitter. He wondered if the plant symbolized the silence 
and discretion of richly attired Moche messengers, some of whom wear belts adorned with Ulluchus. In his 1938 publication, he labeled a Moche fine-line drawing of Ulluchu as Phaseolus sp. (a bean). Larco clearly recognized that Ulluchu had nothing whatsoever in common with "ulluco" (Ullucus tuberosus), an Andean tuber still widely cultivated and consumed in Peru nowadays.

The symbolic importance of Ulluchu in Moche iconography was firmly established by Moche scholar Donnan McClelland [3]. Based upon a meticulous review of the UCLA Moche Archive, she showed that its distribution was non-random and that its varied usage displayed definite patterns with the greatest variability among background elements and the most frequent representation found on the belts of warriors and runners. She demonstrated that "the leaves of the Phaseolus do not resemble the ulluchu leaf depictions" [[3]: 43]. Pepino (Solanum muricatum) and aji (Capsicum annum), which are clearly depicted in Moche art and do not resemble Ulluchu were also eliminated "since the ulluchi $[$ sic] fruit is suspended from the plant by its smaller pointed end, whereas these two are suspended by the large end" [[3]: 437]. She also indicated that the plant had not been botanically identified, pointing out that, if it turned out to be a mythical plant, no identification would be possible.

A decade after McClelland's seminal article, S. Henry Wassen [4] of the Gothenburg Ethnographical Museum, eliminated Persea americana Miller var. americana (a wild relative of avocado) as a candidate, and concluded that Ulluchu was Carica candicans A. Gray (a species of wild papaya). He also co-authored an article describing the enzyme papain, which can be extracted from unripe papaya, for use as a blood anti-coagulant [5]. In the latter article, the authors proposed that papain was used in the Moche sacrifice ceremony to prevent the coagulation of blood drawn from sacrificed warriors for later consumption by priests.

In a paper presented at the Sibley Conference at the University of Texas at Austin, in November 2003, McClelland [6], in addition to updating her 1977 paper in the light of a vastly expanded Moche Archive and archaeological discoveries of real Ulluchu, refuted the papaya hypothesis. She also discussed the presence in the art of yellow oleander seeds (Thevetia peruviana) as legging rattles as well as espingo seeds (Nectandra sp.) which [7] had earlier suggested might have been added to corn beer for medicinal and psychotropic purposes. McClelland concluded that the largest remaining challenge was the identification of Ulluchu.

In the present paper we build on the work of Donna McClelland and the archaeological excavations at Sipán in the Lambayeque Valley $[8,9]$ and at Dos Cabezas in the Jequetepeque Valley in the 1990s [6].

\section{Materials and methods}

The primary focus of this project has been the ethnobotany of medicinal plants used in Northern Peru and Southern Ecuador, and the changes that have occurred since early colonial times. Fieldwork for the present study was conducted in Southern Ecuador from 1995-2000, and in Northern Peru from 2001-2008. In the course of the fieldwork vouchers of all useful plant species sold in the markets of the region were collected after establishing prior informed consent. The specimens were registered under the collection series "RBU/PL," "ISA," "GER," "JULS," "EHCHL," "VFCHL," "TRUBH," and "TRUVANERICA," depending on the year of fieldwork and collection location. Vouchers of all specimens were deposited at the Herbario Truxillensis (HUT, Universidad Nacional de Trujillo), and Herbario Antenor Orrego (HAO, Universidad Privada Antenor Orrego, Trujillo). In order to recognize Peru's rights under the Convention on Biological Diversity, most notably with regard to the conservation of genetic resources in the framework of a study treating medicinal plants, the identification of the plant material was conducted entirely in Peru. No plant material was exported in any form whatsoever. The nomenclature of plant families, genera, and species followed the Catalogue of the Flowering Plants and Gymnosperms of Peru [10] and the Catalogue of Vascular Plants of Ecuador [11]. The nomenclature was compared to the TROPICOS database. Species were identified using the available volumes of the Flora of Peru [12], as well as [13,14] and reference material in the herbaria HUT, HAO, QCA, LOJA, and QCNE.

In addition to documenting the associated use-knowledge, plant collectors, vendors and curanderos (local healers) were interviewed about any possible knowledge of Ulluchu. Also, colonial records about useful plants of the region, which include [15-21] were searched for possible information and iconography of the plant. Photographs of all archeological specimens found, including photographs of the interior fruit structure in broken specimens, were obtained and used for direct comparison to botanical vouchers and life specimens of plant candidates. Ultimately, the available online collections of the Chicago Field Museum, New York Botanical Garden, and Missouri Botanical Garden were checked for possible candidates, and specimens from the Missouri Botanical Garden Herbarium were used for final determination and imaging.

\section{Discussion and Results}

\section{Issues surrounding the name Ulluchu}

The name Ulluchu seems to have been coined by Larco [1]. According to his description, the name originated in the Virú River valley, and is supposedly of Mochica origin. However, there is no linguistic evidence that such a term indeed existed in the Mochica or Yunga language. The most comprehensive Mochica-Spanish dictionary available, compiled from the writings of Moche scholar 
E. Brüning [22], has no such term. In addition, the local population, as well as market vendors, plant collectors, and curanderos interviewed, had no knowledge of Ulluchu whatsoever, other than what they derived from Larco. Since this first publication the term has been copied by all subsequent authors [e.g. $[3,4]]$, without any regard to its validity. It is unlikely that Brüning [22] would have missed the name when doing his research early in the $20^{\text {th }}$ century, if it indeed was still being used. Brüning lists quite a few Mochica plant names, some of which are still used for the same plants today, e.g. "faik" = Acacia macracantha (faique, espino), from "fáçek, fáçke" = spine.

The only language that has a somewhat similar word from which Ulluchu could be derived is Quechua: "uchu" translates to "chili, pepper," while "ullu" translates as "penis." The term "ullu uchu" is sometimes used as a name for Columellia ovata R. \& P. (Columelliaceae), a small highAndean plant, described as "a very thick tree; its wood is suitable for various purposes, and its leaves have febrifugal properties and are very bitter" [21]. However, this plant has no likeness whatsoever to the Moche Ulluchu. Thus we must conclude that the term Ulluchu was most likely coined by Larco [[2]: 98] based on a Quechua term for a species with somewhat similar fruits that has no relation to the species used by the Moche.

\section{Botanical identification}

Why is Ulluchu not Carica candicans?

Carica candicans is a wild relative of papaya (Carica papaya L.). Although the fruits are not marketed, they are occasionally consumed by the local population, and some market vendors and healers interviewed did know the plant under its vernacular name, "mito." Larco $[1,2]$ never mentions the plant in relation to Ulluchu. Assuming that he indeed encountered a plant with that name, it cannot have been $C$. candicans, because this species would have been named "mito."

McClelland [6] argues that Ulluchu "cannot be a papaya, which belongs to a group of plants called 'cauliflory' [i.e., stem flowery].... The flowers and fruit of a cauliflory grow on the trunk of the tree and not on the limbs.... Ulluchus depicted in Moche art, however, hang from limbs. Papaya leaves do not resemble ulluchu leaves, which are triangular, ovoid, or boomerang shapes hanging from limbs. Each large palmate papaya leaf grows on a stem from the top of the tree." However, further complicating this matter, it turns out that C. candicans happens to be one of the few papayas that are not cauliflorous, that have triangular leaves with entire margins, and the fruits do hang from branches. Thus, judging from the iconography alone, $C$. candicans actually could be Ulluchu.

Based on recent archaeological evidence however, $[6,8,9,23]$, it has become clear that the actual fruits found in burials do not resemble C. candicans. In addition, the explanation that papain, might have been extracted by the Moche from unripe papaya for use as a blood anti-coagulant [5], albeit reasonable, does not make much sense from a phytochemical perspective. Cultivated papaya ( $C$. papaya) is often depicted in Moche pottery, and the species contains large amounts of papain. Why would the Moche have resorted to a rare wild species, when they could have used a cultivar with the same properties that grew on their very doorstep? Also, C. candicans fruits are often 10-15 $\mathrm{cm}$. long, and, while this would relate to the size of some of the Ulluchus in the iconography, it is vastly larger than many of the fruits depicted and much larger than the fruits
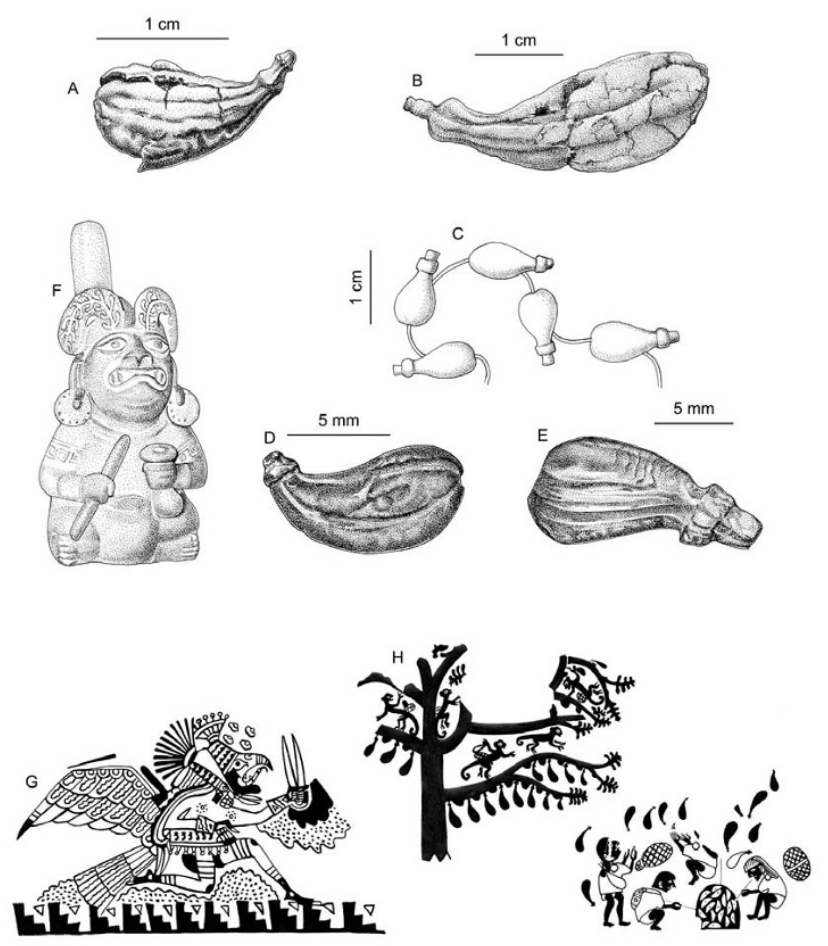

\section{Figure I}

Ulluchu in archaeological context. A. Ulluchu fruit from cache at Sipán. After photograph by Christopher B. Donnan. B. Ulluchu fruit from Dos Cabezas burial. After photograph by Donald McClelland. C. Bone beads in form of Ulluchus fron Huaca de la Luna. After photograph by Donald McClelland. D. Golden Ullucho bead. After photograph by Donald McClelland. E. Spondylus shell bead in form of Ulluchu. After photograph by Donald McClelland. F. Supernatural figure seated holding a gourd, possibly containing ground Ulluchu seeds with Ulluchus painted on headdress. Private collection. After photograph by Christopher B. Donnan, in McClelland ([6]: Fig. Three. 18). G. Anthropomorphized hawk runner carrying a snuff tube with Ulluchus on its belt and Ulluchu seeds floating above it. The Art Institute of Chicago. After drawing by Donna McClelland in McClelland ([6] Fig.

Three. 12). H. Ulluchu harvest. Note tree with opposite leaves and extracted seeds on bottom right. After McClelland ([6]: Fig. Three.34), Private collection. 
found in burials. Finally, the anatomy of C. candicans simply does not correlate with the fruits encountered in burials.

\section{What is Ulluchu, and what was it really used for?}

Moche fine-line drawings of Ulluchu normally depict seed pods or seeds floating in the air in sacrificial scenes (e.g., [6] Fig. Three.14), associated with runners and messengers (e.g., [6]: Fig. Three.1) or intoxicated priests (e.g., [6]: Fig. Three.6). The Ulluchu fruits vary greatly in size, ranging from about $1-15 \mathrm{~cm}$. They are normally commashaped, often with an "exaggerated round calyx" [[6]: 43] with lines on the body of the fruit (e.g., [6]: Fig. Three.4). Some illustrations show Ulluchu harvested by monkeys, and in such cases the fruit is mostly shown growing along the axes of the plant's leaves (e.g., [6]: Figs. Three.27 \& Three.28).

Starting from this basis in 2002, we built on the work of Donna McClelland and the archaeological excavations at Sipán in the Lambayeque Valley $[8,9,24]$ and at Dos Cabezas in the Jequetepeque Valley in the 1990s [6,23]. Botanically, all these depictions resemble capsules or drupe-like fruits. It became apparent that in a biodiversity hotspot like Peru, with a flora of more than 18.000 species, a large number of plant families have fruits that vaguely resemble Moche fineline drawings of Ulluchu, and many of these families contain more than one genus with similar fruits. Examples include: (Apocynaceae: Ambelania; Caricaceae: Carica; Celastraceae: Maytenus; Chrysobalanaceae: Chrysobalanus, Hirtella, Licania; Convolvulaceae: Dicranostyles; Fabaceae: Aldina, Alexa, Andira, Dipteryx, Dussia, Ormosia; Guttiferae: Tovomita; Hippocrateaceae: Cheiloclinum, Sala-

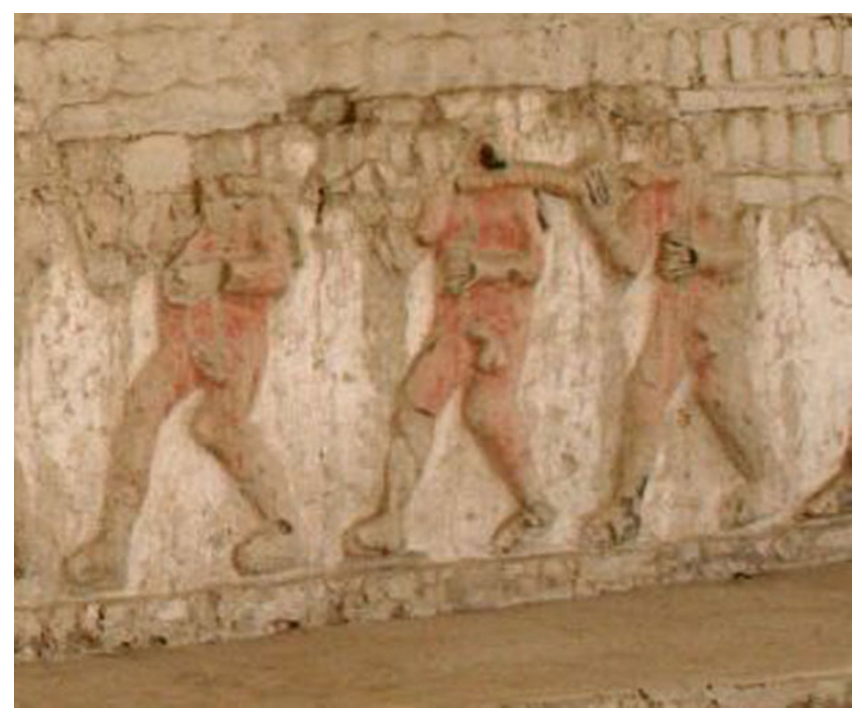

Figure 2

Line of prisoners at Huaca EI Brujo. Photo by Rainer W. Bussmann. cia; Icacinaceae: Calatola; Meliaceae: Guarea; Menispermaceae: Abuta, Curarea, Elephantomene, Telitoxicum; Myristicaceae: Virola; Olacaceae: Cathedra; Quiinaceae: Lacunaria; Sabiaceae: Meliosma; Sapindaceae: Cupania, Paullinia; and Sapotaceae: Pouteria. Some of these are still highly important in traditional societies. For example, Ambelania fruit is often consumed; Ormosia contains potent poisonous compounds, but is now mostly used in crafts; Curarea is one of the ingredients of "curare," the famous Amazonian arrow poison; Virola species are still used as potent snuffs in the Amazon; and Paullinia is the source of "yopo," an important stimulant. However, none of these carry the vernacular name Ulluchu.

Fortunately, at this time the archaeological evidence provides good clues for identification. The Ulluchu fruits found in burials in the 1990's are clearly capsules or drupes, slightly comma-shaped, between 1.5 and $5 \mathrm{~cm}$. long, and slightly grooved (Fig. 1A\&1B). They closely resemble bone, gold, and Spondylus beads found in situ in size, form, and texture (Fig. 1C-E). In the iconography, the fruits are often depicted on both sides of branches, as in the headdress of Fig. 1F. It is important to note that this figure has widely extended nostrils, as is often seen in people inhaling hallucinogenic snuffs, and is holding a gourd and pestle. McClelland ([6]: Fig. Three.18) interpreted this as lime gourd used for chewing coca. We suggest that this might also be a gourd used to grind the seeds of Ulluchu for inhalation. Further iconographic evidence supports this hypothesis. Runners and messengers associated with Ulluchu are often winged - they literally fly, i.e., the inhalation of Ulluchu gives them wings. An excellent example is the runner depicted in Fig. 1G: The personage has Ulluchu on his belt, Ulluchu seeds floating above its head, and an instrument in his hand that closely resembles a typical double snuff tube that would serve to inhale powdered hallucinogenic substances. Thus, it seems possible that one of the uses of Ulluchu may have been as a mind-altering snuff. Another reason for identifying the seeds in the iconography as hallucinogenic Ulluchus is underscored by Fig. 1H: This is part of a famous Moche scene (see [6]: Fig. Three.34) where monkeys are picking fruits from an Ulluchu tree. It is important to note that the tree depicted has opposite leaves and that seeds are extracted from the fruit, possibly for roasting in a typical oven on the bottom right. The roasted seeds could then be ground to powder and inhaled. The fruits themselves seem to be 5-valved. The function of Ulluchu as a hallucinogen is reinforced by other imagery (e.g., [6]: Fig. Three.6), where personages, surrounded by Ulluchu fruits lie on the ground in what clearly appears to be an intoxicated state. In addition, prisoners in sacrificial scenes (e.g., [25]: Figs. Two.2, Two.3, Two.12 \& Two.24), especially the well known "lines of prisoners" at Huaca El Brujo and Huaca de la Luna (Fig. 2) all show clearly visible erections, 


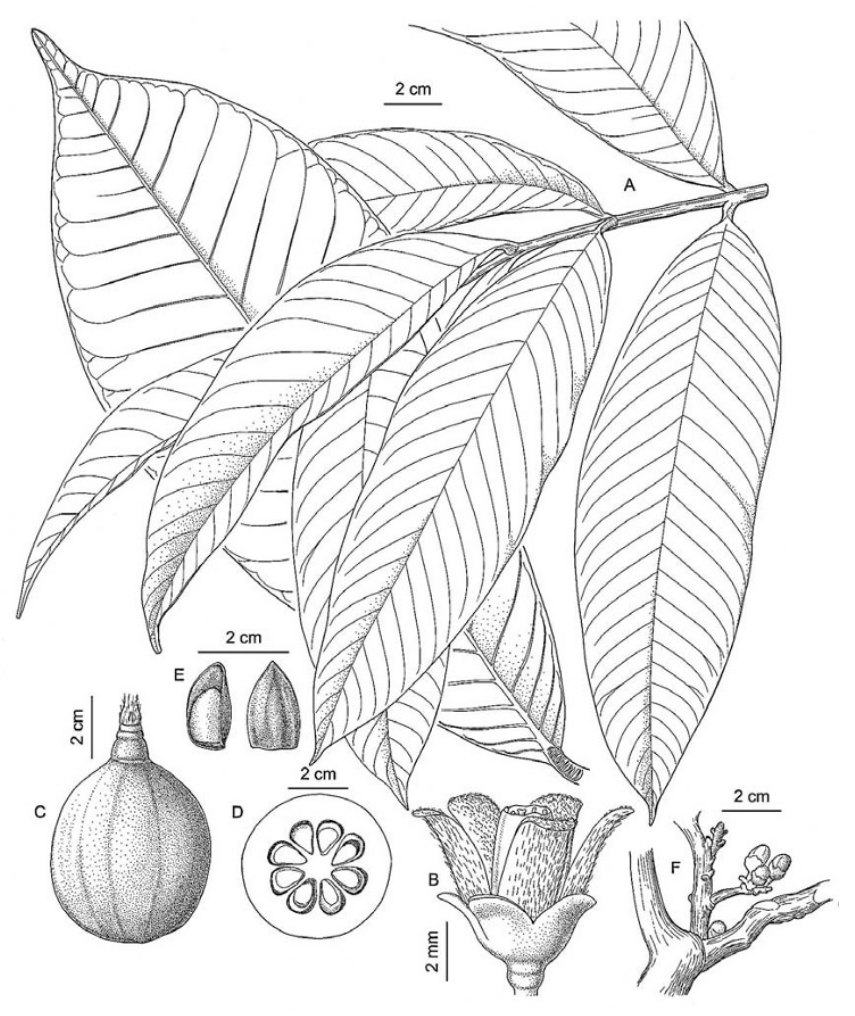

Figure 3

Guarea grandifolia. A. Mature branch. B. Flower. C. Mature fruit. D. Fruit cross section. E. Seeds F. Branching pattern.

which may be seen as another indication of the ingestion of some substance causing this effect. From this perspective Larco's term Ulluchu [2], if derived from Quechua "ullu-uchu" - "penis pepper," would in fact make sense in describing the possible effects of the plant in question. Also, the association with sexual arousal is reinforced by mythical scenes where an Ulluchu tree grows out of the back of an erotic couple.

In light of the above, Ulluchu is a tree with opposite leaves and fruits that are drupes between 1-15 cm long possibly containing active ingredients that would elevate the blood pressure and cause erections, and psycho-active substances. The only plant family from the list above having representatives that meet all these criteria is Meliaceae, and the genus Guarea is the one that most closely fits the description. It includes mostly trees with pinnate leaves (which is unusual for Meliaceae), and fruits that are 3-5 valved capsules, with large, pseudo arillate seeds. The genus Guarea is found throughout Peru, but is mostly restricted to tropical lowland forests, with some species reaching cloud forest habitat. No species is found along the dry coast of Peru, which indicates that the material must have been widely traded in Moche times. A typical representative is Guarea grandifolia DC. The species has clearly pinnate leaves (Fig. 3A), and the fruits (Fig. 3C) very clearly resemble the archaeological samples depicted in Fig. 1. In addition, Guarea contains a large number of species with varying fruit sizes (from 1-15 cm.), calyx swelling, and grooving on the body of the fruit (Fig. 4), which all correlates with the varied Ulluchu imagery in Moche fineline drawings. The seeds of Guarea species, with a distinct white navel, very much resemble the seeds depicted in Moche fineline paintings.

Many species of Guarea are known by a wide variety of vernacular names, e.g., Guarea spec.: requia, kushímsakish; G. glabra: yecheñor, yechemor; G. grandifolia: bola requia; G. guidonia: atapio, latapi, latapi caspi, requia colorada, requia latapi, xoro; G. kunthiana: requia, paujil ruro; G. purusana: latapi, requia). The wood of many species is used as timber for construction. The wood, bark, and leaves contain compounds that act as abortive, emetic, purgative, and antiamoebiac agents, and the bark is often sold as Coccilliana in expectorant preparations [12,26-28]. The fruits and seeds contain a variety of alkaloids that are very rarely used due to their high toxicity [29]. Some of the alkaloids found, e.g. rusbyine, have a structure and effects like emetine, an alkaloid found in Psychotria ipecacuanha (Brot.) Stokes, which has been widely used as an emetic and expectorant. Other species of Psychotria are well

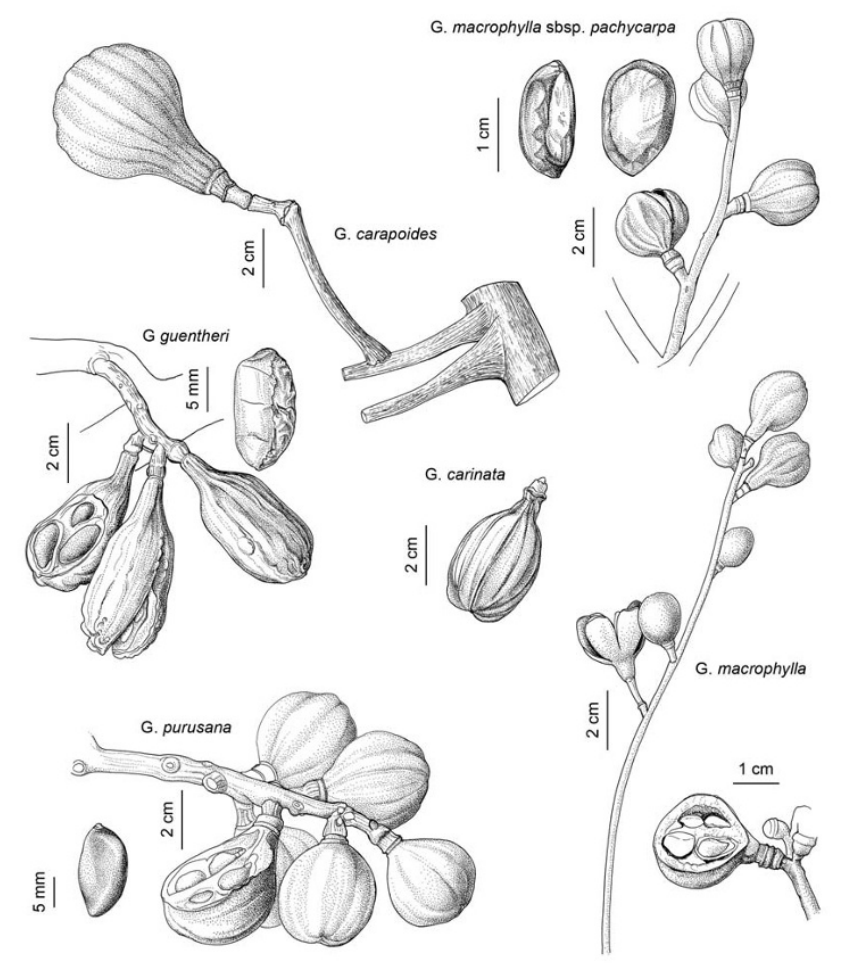

Figure 4

Fruits of various species of Guarea (G. macrophylla with seeds, G. carapoides, G. carinata, G. macrophylla, G. purusana with seeds, $\mathbf{G}$. guentheri with seeds). 
known as components in ayahuasca preparations due to their high content of $\mathrm{N}, \mathrm{N}-\mathrm{DMT}$ [30]. In large dosages, ipecac preparations cause high blood pressure, arrhythmia, spasms, and extension of the blood vessels. While the existing literature on Guarea seed compounds is rather fragmentary, it seems clear that a concentrated dosage of Ulluchu seeds, if ingested, would increase a prisoner's heartbeat, elevate the blood pressure, and widen blood vessels thus causing erection. All of this would make it much easier to extract sacrificial blood. Also, when inhaled by priests, the active compounds could have a mind-altering effect, which would not necessarily lead to high levels of toxicity, and could induce very rapid, shortterm hallucinations.

\section{Conclusion}

We conclude that Ulluchu can be identified as a group of species of the genus Guarea (Meliaceae) based on morphological characteristics. In addition, the chemical composition of the plant's compounds supports the theses of $[3,4]$ that it was used in a sacrificial context to improve the extraction of blood from sacrificial victims. We also suggest that a ground preparation of Guarea seeds, when inhaled, may have been used as a hallucinogen. However, more detailed phytochemical research is needed to corroborate the latter hypothesis.

\section{Declaration of Competing interests}

The authors declare that they have no competing interests.

\section{Authors' contributions}

Both authors share the contributions to fieldwork, data analysis, and compilation of this manuscript. All authors read and approved the final manuscript.

\section{Acknowledgments}

Manuscript in memory of Donna McClelland.

The present study was financed through MIRT (Minority International Research and Training) or MHIRT (Minority Health Disparity International Research Training) as it was recently renamed, a grant from the National Institutes of Health (Fund: 54I I 2B MHIRT Program, Grant: G00006 I3), initially administered by the Fogarty International Center for Advanced Studies in Washington, D.C. MHIRT-Peru is coordinated by San Diego State University (SDSU) in cooperation with the San Diego Museum of Man (SDMOM), the P.A. Hearst Museum of Anthropology at the University of California Berkeley (PAHMA-UCB), and the University of Hawaii at Manoa in the US, as well as the Universidad Privada Antenor Orrego (UPAO, Herbarium HAO), the Universidad Nacional de Trujillo (UNT, Herbarium HUT and Instituto de Medicina Tropical) and the Clínica Anticona Trujillo (CAT) in Peru. We owe a great debt of gratitude to Donna McClelland, who unfortunately did not live to see the solution to the riddle that she worked on for decades. Special thanks go to Christopher Donnan and Don McClelland for putting us on the track of Ulluchu and supplying photographs of all of the archaeological evidence available. Finally many thanks to Barbara Alongi at MBG, who provided the detailed drawings for Figures I, 3, and 4.

\section{References}

I. Larco Hoyle R: Los mochicas I Casa editora "La Crónica" y "Variedades", S. A. Ltda. Lima; 1938.

2. Larco Hoyle R: Los Mochicas I/ Casa editora "La Crónica" y "Variedades", S. A. Ltda. Lima; 1939.

3. McClelland D: The Ulluchu: A Moche Symbolic Fruit. In PreColumbian Art History Edited by: Cordy-Collins A, Stern J. Peek Publications, Palo Alto; 1977:435-452.

4. Wassen H: "Ulluchu " Moche Iconography and Blood Ceremonies: The Search for Identification. Göteborg Etnografiska Museum, Annals 1985/86 1987.

5. Hultin E, Wassén H, Bondeson W: Papain in Moche Blood ceremonies. Journal of Ethnopharmacologie 1987, 19(2):227-228.

6. McClelland D: Ulluchu - An elusive fruit. In The Art and Archaeology of the Moche Edited by: Bourget S, Jones KL. University of Texas Press, Austin; 2008:43-65.

7. Wassen H: Was Espingo (Ispincu) of Psychotropic and Intoxicating Importance for Shamans in Peru? In The Realm of the Extra-Human Agents and Audiences Edited by: Agehananda Bharati. Mouton Publishers, The Hague-Paris. Distributed in the United States and Canada by Aldine, Chicago; 1976.

8. Alva W, Donnan CB: Royal Tombs of Sipán Fowler Museum of Cultural History, University of California, Los Angeles; 1993.

9. Alva W: Sipán: descubrimiento y investigación. Cultura y artes del antiguo Perú Backus y Johnston, Lima; 1994.

10. Brako L, Zarucchi JL, (Eds): Catalogue of the Flowering Plants and Gymnosperms of Peru Missouri Botanical Garden, Saint Louis, MO; 1993.

II. Jørgensen PM, León-Yañez S, (Eds): Catalogue of the vascular plants of Ecuador. Monographs in Systematic Botany from the Missouri Botanical Garden 1999, 75:

12. McBride JF, (Ed): Flora of Peru Fieldiana: Botany. Field Museum of Natural History, Chicago; 1936.

13. Jørgensen PM, Ulloa Ulloa C: Seed plants of the High Andes of Ecuador - a Checklist. AAU Reports 1994, 34: I-443.

14. Ulloa Ulloa C, Jørgensen PM: Arboles y arbustos de los Andes del Ecuador. AAU Reports 1993, 30:1-263.

15. de Acosta J: Historia natural y moral de las Indias. Sevilla $\mathbf{1 5 9 0 .}$

16. de Alcedo A: Diccionario geográfico histórico de las indias occidentales o América. Madrid 1786.

17. Cobo B: Historia del Nuevo Mundo, 2 tomos. Sevilla 1653.

18. Cobo B: Historia del Nuevo Mundo Edited by: Francisco de Mateos. Ediciones Atlas, Madrid; 1956.

19. Monardes N: Primera y segunda y tercera partes de la história medicinal de las cosas que se traen de nuestras Indias Occidentales, que sirven en medicina; Tratado de la piedra bezaar, y dela yerva escuerçonera; Diálogo de las grandezas del hierro, y de sus virtudes medicinales; Tratado de la nieve, $y$ del beuer frio Alonso Escrivano, Seville; 1574.

20. Marínez Compañon DB: Razón de las especies de la naturaleza y del arte del obispado de Trujillo del Perú. Tomos III-V 1789.

21. Ruiz H: Relación del viaje hecho a los reynos del Perú y Chile. I777-I 788 Translated by Schultes ER, Nemry von Thenen de Jaramillo-Arango MJ as "The Journals of Hipólito Ruiz, Timber Press, Portland; 1998.

22. Brüning HH: Diccionario Mochica Universidad de San Martin de Porres, Lima; 2004

23. Donnan $\mathrm{CB}$, Castillo LJ: Excavaciones de tumbas de sacerdotes Moche en San José de Moro, Jequetepeque. In Travaux de I'Institut Français d'Etudes Andines Volume 79. Edited by: Uceda S, Mujica E. Moche: Propuestas y Perspectivas, 5; 1994:4I 5-442.

24. Alva W, Donnan CB: Tales from a Peruvian Crypt. Natural History 1994, 103(5):26-36.

25. Hocquenghem AM: Sacrifices and Ceremonial Calendars in Societies of the Central Andes: A Reconsideration. In The Art and Archaeology ofthe Moche Edited by: Bourget S, Jones KL. University of Texas Press, Austin; 2008:23-42.

26. Soukup J: Vocabulario de los nombres vulgares de la flora peruana Imp. Colegio Salesiano, Lima; 1970.

27. Soukup J: Vocabulario de los nombres tradicionales de la Flora Peruana y catálogo de los géneros Editorial Salesiana, Lima; 1987.

28. Brack Egg A: Diccionario enciclopédico de plantas útiles del Perú $\mathrm{CBC}$ Cusco; 1999.

29. Kraemer H: Scientific and Applied Pharmacognosy. Philadelphia 1915.

30. Rätsch C: Enzyklopädie der psychoaktiven Pflanzen AT Verlag, Aarau; 1998. 